\title{
Stāvoklis Latvijā 1919. gada jūlijā: Lielbritānijas pārstāvju viedoklis
}

\author{
Situation in Latvia in July 1919: The Perspective \\ of British Representatives
}

Dokumentus publicēšanai sagatavojis, no ang!u valodas tulkojis un komentējis Translation and commentaries by

Ëriks Jēkabsons, Dr. hist.

Latvijas Universitātes Vēstures un filozofijas fakultātes

Vēstures un arheoloǵijas nodalas profesors

Aspazijas bulvāris 5, Rīga, LV-1050

E-pasts:eriks.jekabsons@lu.lv

Latvijas Neatkarības kara vēsturē joprojām ir samērā daudz jautājumu, kuri nav pilnībā izpētīti. 1918.-1920. gadā Latvijas Pagaidu valdības vadībā Latvijas valsts cīnījās par savu neatkarību ārkārtīgi sarežğîtā un grūtā situācijā. To izteiksmīgi apliecina fakts, ka tolaik Latvijas teritorijā atradās un cīnās piedalījās 14 dažādu bruṇoto spēku vienības (Latvijas, padomju Latvijas, provāciskās Latvijas valdības, Krievijas Sarkanās armijas, Vācijas, Bermonta, topošās Krievijas Ziemeḷrietumu armijas, vācbaltiešu vienības, kuras to darbības rakstura un iespaida dēḷ var ieskaitīt šajā kategorijā, Igaunijas, Polijas, Lietuvas armijas, Baltkrievijas Tautas Republikas brun,otie spēki), minētajam var pieskaitīt arī Lielbritānijas un Francijas karakuğus un Francijas tankus un tankistus Polijas armijā, kā arī vēl vismaz astoṇu nacionalitāšu vienības citu armiju sastāvā (somu un dāṇu - Igaunijas armijā, baltkrievu - Lietuvas armijā, latviešu, igauņu un k̦iniešu Sarkanajā armijā, vācbaltiešu un krievu - Latvijas Pagaidu valdības spēkos). Jāievēro arī vairāku Lielbritānijas, ASV un Francijas misijas klātbūtne. Minēto ņemot vērā, saprotam, kāpēc milzīgi daudz joprojām lielā mērā nezināmas informācijas par šo karu glabājas ārzemju arhīvos.

1919. gada jūnija beigās un jūlija beigās Latvijā noslēdzās Cēsu kaujas, igauṇu artilērijai uzsākot Rīgas bombardēšanu, kurā bija arī civiliedzīvotāju upuri. 2. jūlijā igauņu karakug̣u eskadra ieņēma Mangaḷsalu un Vecmīlgrāvi. Rīgu steigšus pameta Andrieva Niedras provāciskā valdība un pakāpeniski arī vācu militārie spēki, kam sekoja vairāki tūkstoši vācbaltiešu bēg̣̣u - civiliedzīvotāju. 2. jūlijā Rīgā iestādes savā apsardzībā pārṇēma Jāṇa Baloža komandētā brigāde. ${ }^{1}$ 
Uzvara pie Cēsīm deva arī iespēju Kārḷa Ulmaņa Pagaidu valdībai 27. jūnijā nokāpt no kuğa Liepājā, bet 8. jūlijā atgriezties Rīgā. Līdz ar to tā pārṇēma kontroli pār Latvijas teritoriju, kas bija atbrīvota no boḷ̌šviku varas. Beidza pastāvēt A. Niedras provāciskā valdība, un iespaidu zaudēja padomju Latvijas valdība. ${ }^{2}$ Ievērojama loma šajos procesos un norisēs bija Rietumu lielvalstu misijām. Tieši ar viṇu aktīvu līdzdalību starp vācu un igauṇu spēkiem tika panākta t. s. Strazdumuižas pamiera parakstīšana 1919. gada 3. jūlijā. Cita starpā tas paredzēja, ka vācu karaspēkam līdz 5. jūlijam pilnībā jāatstāj Rīga un jāgatavojas iziešanai no Latvijas teritorijas uz Vāciju. No Rīgas vācu spēki tika izvesti, izveidojot pamatbāzi Jelgavā un tās apkārtnē. ${ }^{3}$ Faktiski uzreiz starp vācu un latviešu vienībām sākās sadursmes, ko pavadīja regulāras vācu karaspēka laupīšanas, kā arī nicīga izturēšanās pret vietējām varas iestādēm Zemgalē. ${ }^{4}$

Sabiedrotie 1919. gada vasarā centās panākt jautājuma noregulējumu un vācu karaspēka ātrāku izvešanu no Latvijas teritorijas. Tas pilnībā neapmierināja Vācijas spēkus komandējošo 6. rezerves korpusa komandieri Rīdigeru fon der Golcu, kurš šajā situācijā gan bija spiests izrādīt gatavību sadarboties ar sabiedroto misijām. Pirmā abu pušu tikšanās pēc sabiedroto kopējās misijas vadītāja Huberta Gofa priekšlikuma notika 19. jūlijā Vintapu mājās pie Olaines stacijas (18. jūlijā H. Gofs Rīgā apspriedās ar Latvijas Ministru prezidentu Kārli Ulmani). Tikšanās Vintapos praktiski neko nedeva, ${ }^{5}$ tāpat kā sabiedroto, Lielbritānijas, Francijas un ASV misiju tālākie centieni noregulēt attiecības un panākt Vācijas karaspēka izvešanu uz Vāciju. Zemgalē un Kurzemē minētie vācu spēki, kuri atgriezties Vācijā nevēlējās, apvienojās ar pretboḷ̌sevistiskajām krievu vienībām, kas bija atbraukušas no Vācijas. Tā izveidojās Pāvela Bermonta komandētā Rietumkrievijas Brīvprātīgo armija, kas oktobrī uzsāka karadarbību pret Latvijas bruṇotajiem spēkiem, bet novembra beigās tika pilnībā padzīta no Latvijas teritorijas.

Tālāk publicēti sabiedroto misijas vadītāja H. Gofa un Lielbritānijas Ārlietu ministrijas pārstāvja Herberta Granta-Vatsona ziņojumi par norisēm un noskaņojumu Latvijā 1919. gada jūlija vidū. Ziṇojumi glabājas Apvienotās Karalistes Nacionālajā arhīvā Londonā, Ârlietu ministrijas kolekcijā.

Abu ziņojumu autori rakstīšanas brīdī ir labi iepazinuši stāvokli Liepājā un Rīgā. H. Grants-Vatsons, pēc ilgākām, nedrošās politiskās situācijas dēḷ radītām šaubām par savu turpmāko darbavietu (Liepāja vai Rīga) no Liepājas ieradās Rīgā 17. jūlija vakarā, konstatējot, ka stāvoklis pilsētā ir "tuvu panikai" un ka to izraisījušas runas par "vācu un krievu aktivitātēm Kurzemē". ${ }^{6}$ Abi balstījās ne vien uz informāciju, ko ieguva sarunās ar Latvijas valdības pārstāvjiem, bet arī personiskiem novērojumiem. Faktiski ziṇojumos ietverta informācija par stāvokli Rīgā, bažām par Zemgalē un Kurzemē notiekošo (cita starpā redzams, ka Latvijas valdība jau jūlija vidū precīzi paredzēja notikumu tālāko attīstību), sabiedroto misiju savstarpējām attiecībām u. c. būtiskiem jautājumiem, kas līdz šim historiogrāfijā aplūkoti vienīgi vispārīgi. Sākotnēji sniegts dokumenta oriǵinālteksts angḷu valodā, pēc tam - tulkojums latviešu valodā ar komentāriem un skaidrojumiem.

\section{Document No. 1}

Excerpt of Report of Head of British Mission to Baltic States Hubert Gough to the War Office, Helsinki, July 16, 1919 
$[\ldots]$

Latvia. I am just back from RIGA and LIBAU, where the situation was most instructive. I am glad to see that in spite of the French at GRODNO and our vice-consuls and other alarmists, who have never been trained to act or take responsibility, Carton de Wiart agrees with me that solution of all difficulties in this part of the world is immediate evacuation by the Germans.

By the time this letter reaches you, the evacuation of RIGA by the Germans will have been forgotten and the fact simply filled as having occurred. In reality, the whole affair should be carefully memorised by those who will have future dealings with the Germans.

In spite of wails from Americans and from our viceconsuls and even the S.[enior] N. [aval] O.[fficer] at Libau, the Esthonian Army forced the Germans to obey our decisions, and thus liberated Latvia from a tyranny, did a very great deal to clear the Baltic Provinces from German power and influence and thus also enabled these countries to organise against Bolshevik aggression.

The Germans already short circuited me by refusing to deal with me direct and by informing PARIS that they were evacuating Latvia and that Von Der Goltz had forbidden his troops to advance northwards. Four days after this deliberate lie, Von der Goltz ordered the Landeswehr supported by the Germans to attack the Esthonians; had that been successful, Latvia would not be evacuated now and LIBAU and RIGA not be the happy free towns.

In this respect, I attach as Appendix B. a copy of an address given me in Riga on my arrival. It is self-explanatory and should be digested by Mr. Hoover. [...]

The stories told him about Esthonians firing gas into the city and the dreadful things that would happen if the Germans were driven out, etc. were quite unfounded and entirely of German origin. An alarmist telegram sent out in clear by American from the city was handed to him by Fletcher the German General and American signed his name to it!

In justice to Americans I must say that they were ashamed of the incident and sent out a full denial a day later but the mischief was done. I do not blame the Americans any more than those of our own people who are easily humbugged by the Germans. I all my dealings with the Americans I have found them straight-forward and eager to correct any error made. I have had the greatest assistance from them and they belong to the few people I can depend upon once they have got a grip of the subject. If it were only possible that Allied Missions were in future to be composed of British and Americans only how much more easily everything could be settled.

Whilst at Riga, I arranged for Colonel Alexander (Irish Guards) to take command temporarily of the Landeswehr which consisted of 284 Officers and 4533 Other Ranks of German Baltic origin and 295 Officers and 2694 Other Ranks pure German.

All the Germans are to be returned to Germany forthwith and the Baltic formed into a unit which will be incorporated into one of the divisions of the Latvian Army. General Burt has made his Headquarters at Riga and has started to organise the new Latvian Army at once.

Colonel Tallents the F. [oreign] O.[ffice] representative now that he is settled down in functioning very well indeed and has dealt with a most difficult situation with firmness and tact.

Prince Lieven troops are to be dispatched to the Russian North West Army where in spite of their German orientation I hope they will make good. At all events they will 
be much further from German influence at NARVA and fortunately we are making by degrees a very anti-German barrier in Latvia between NARVA and BERLIN.

Finance has been our chief difficulty; if we had a few millions to meet the many calls in these countries one could accomplish much. Colonel Tallents has the doubtful privilege of negotiating loans and dealing with finance generally, and I hope to see soon more result in answer to his repeated enquiries. I would however again strongly urge that the secret of the return of prosperity to these countries is the immediate opening of trade and commerce. Loans are required to enable them to pay for their first and most pressing demands. I would suggest that private or Government firms who deal in machinery should be asked to send out representatives at once to these countries to see what is required and register orders.

Lithuania [...].

Source: National Archives (United Kingdom), Foreign Office, 371/3615/420-422.

\section{1. dokuments}

Izvilkums no sabiedroto misijas vadītāja Baltijas valstīs Huberta Gofa ${ }^{7}$ ziṇojuma Lielbritānijas Kara ministrijai. Helsinki, 1919. gada 16. jūlijs.

[...]

Latvija. Esmu tikko atgriezies no RĪGAS un LIEPĀJAS, kur stāvoklis bija l,oti pamācošs. Es priecājos, ka, par spīti frančiem GRODN̦Ā, ${ }^{8}$ mūsu vicekonsuliem ${ }^{9}$ un citiem trauksmes cēlējiem, kuri nekad nav tikuši apmācīti rīkoties un uzṇemties atbildību, Kartons de Viarts $^{10}$ piekrīt man, ka visu grūtību risinājums šajā pasaules daḷā ir nekavējoties izvest vāciešu [karaspēku].

Laikā, kad šì vēstule Jūs sasniegs, vācu karaspēka izvešana no RĪGAS jau būs aizmirsta un vienkārši piefiksēta kā noticis fakts. Patiesībā tiem, kam turpmāk būs darīšanas ar vāciešiem, rūpīgi jāiegaumē viss notikušais.

Neraugoties uz amerikāṇu, mūsu vicekonsulu un pat V[ecākā] f[lotes] v[irsnieka] Liepājā vaimanām, ${ }^{11}$ Igaunijas armija piespieda vāciešus pakḷauties mūsu lēmumiem un tādējādi atbrīvoja Latviju no tirānijas, deva lielu ieguldījumu, lai atbrīvotu Baltijas provinces no vācu varas un iespaida, kā arī deva iespēju šìm valstīm organizēties, lai cīnìtos pret boḷševiku agresiju.

Vācieši jau tika izslēguši mani no informācijas aprites, atsakoties risināt situāciju tiešā sazin̄ā ar mani ${ }^{12}$ un tā vietā informējot PARĪZI, ka viṇi izved karaspēku no Latvijas, turklāt fon der Golcs ${ }^{13}$ ir aizliedzis savam karaspēkam virzìties uz ziemeḷiem. Četras dienas pēc šiem apzinātajiem meliem fon der Golcs pavēlēja landesvēram, ko atbalstīja vācieši, uzbrukt igauniiem; ${ }^{14}$ ja uzbrukums būtu bijis veiksmīgs, tagad karaspēks no Latvijas nebūtu izvests un LIEPĀJA un RĪGA nebūtu laimīgas brīvas pilsētas.

Tādēl es pievienoju kā pielikumu "B" kopiju no adreses, ${ }^{15}$ kādu man iesniedza, ierodoties Rīgā. ${ }^{16}$ Tā runā pati par sevi un būtu jāielāgo Hūvera ${ }^{17}$ kungam. [...]

Viss, kas viṇam ticis stāstīts par igauṇiem, kuri šauj uz pilsētu ar gāzi pildītus lādinus, un par šausmīgajām lietām, kas var notikt, ja vācieši tiks padzīti utt., bija galīgi nepamatots un pilnībā nāca no vāciešiem. Trauksmi sacēlušo telegrammu, kuru no pilsētas nosūtīja amerikānis, viṇam iedeva Flečers, ${ }^{18}$ vācu generālis, ${ }^{19}$ un amerikānis to parakstīja ar savu vārdu! ${ }^{20}$ 
Lai būtu taisnīgs pret amerikāṇiem, man jāteic, ka viṇi jutās ḷoti neērti par notikušo un dienu vēlāk nosūtīja ziṇu, pilnībā noliedzot visu [telegrammā] teikto, taču l̦aunums jau bija nodarīts. Es nevainoju amerikāṇus vairāk kā tos mūsu pašu cilvēkus, kurus vācieši viegli apmuḷ,ko. Visās darīšanās ar amerikāņiem es konstatēju, ka viņi ir godīgi un l,oti vēlas labot jebkuru pieḷauto kḷ̂udu. Esmu saṇēmis no viņiem lielāko atbalstu, un amerikāṇi pieder pie tiem nedaudzajiem cilvēkiem, uz kuriem es varu palauties, kad viṇi ir izpratuši lietas būtību. Ja vien būtu iespējams nākotnē sabiedroto misijas veidot vienīgi no britiem un amerikāņiem, visu varētu atrisināt daudz vieglāk.

Atrodoties Rīgā, es nokārtoju, ka pulkvedis Aleksanders ${ }^{21}$ (Īru gvardi) pagaidām uzṇemas komandēt landesvēru, kas sastāvēja 284 vācbaltiešu virsniekiem un 4533 citu dienesta pakāpju vācbaltiešu karavīriem un 295 virsniekiem un 2694 citu dienesta pakāpju karavīriem, kuri bija tīri vācieši. ${ }^{22}$

Visiem vāciešiem [no landesvēra] nekavējoties jābūt nosūtītiem atpakal, uz Vāciju, un vācbaltieši jāapvieno vienībā, kura tiks iekḷauta vienā no Latvijas armijas divīzijām. G̣enerālis Bērts ${ }^{23}$ ir izveidojis savu štābu Rīgā un uzreiz ir sācis organizēt jauno Latvijas armiju. $^{24}$

Pulkvedis Talentss, ${ }^{25} \bar{A}$ [rlietu] m[inistrijas] pārstāvis, pašlaik ir tiešām l,oti labi sakārtojis savu darbību un noteikti un taktiski rīkojas vissarežĝ̀îtākajā situācijā. ${ }^{26}$

Firsta Līvena ${ }^{27}$ karaspēks ir jānosūta uz Ziemel̦ietumu Krievijas armiju, kur, neraugoties uz vācisko orientāciju, cerams, būs noderīgs. Jebkurā gadījumā NARVĀ viṇi būs daudz tālāk no vācu ietekmes, un, par laimi, mēs Latvijā pakāpeniski veidojam l,oti pretvācisku barjeru starp NARVU un BERLĪNI.

Finanses ir bijušas mūsu galvenais šḳērslis; ja mums būtu daži miljoni, lai atbalstītu daudzās šo valstu vajadzības, varētu izdarīt daudz. Pulkvedim Talentsam ir šī apšaubāmā privilēgija vienoties par aizdevumiem un risināt finanšu jautājumus vispārīgi, un es ceru drīzumā sagaidīt, ka viņa atkārtotajiem pieprasījumiem būs rezultāti. Es tomēr atkal stipri mudinātu izprast, ka labklājības atgriešanās noslēpums šajās valstīs slēpjas tirdzniecības un tirgošanās atjaunošanā. Ir nepieciešami aizdevumi, lai dotu tām iespēju samaksāt par to pirmajām un visakūtākajām vajadzībām. Es piedāvātu lūgt privātiem un valsts mašinērijas uzṇēmumiem uzreiz nosūtīt pārstāvjus uz šìm valstīm, lai noskaidrotu, kas nepieciešams, un pieņemtu pasūtījumus.

Lietuva [...].

Avots: National Archives (United Kingdom), Foreign Office, 371/3615/420-422.

\section{Document No. 2}

Report of Representative of Foreign Office Herbert Grant-Watson to the Acting Foreign Secretary George Curzon, Riga, July 23, 1919

My Lord, With reference to my despatch No. 39 of the $2^{\text {nd }}$ inst., I have the honour to report that the German policy towards the Baltic States is still mainly directed by Herr Winnig who, in addition to his duties as High Commissioner for East Prussia, acts as German Representative in Latvia and Esthonia. He enjoys great influence in East Prussian circles as also with the majority Socialists in Berlin; but those who are well acquainted with his work state that he is not-far seeing and that he has no grasp of reality. Under the influence of drink and other stimulants he is quick to seize at new ideas, but as regards 
Latvia, the policy which he has advocated has been opportunist. When the revolution broke out in December he worked for the recognition of the independence of the Baltic Provinces and for the strengthening of the local national forces to build a dam against the Bolshevik tide. The forces, however, showed themselves hostile to Germany. Later, when the growth of the Polish army seemed to threaten East Prussia, he favoured the formation of a Staatenbund between East Prussia, Lithuania and Latvia, but again he failed to see that such a scheme was doomed to failure because of fundamental national antipathies. More recently the policy of Germany of forming Russian forces in Courland in close touch with Germany to hold the Bolshevik front and to check the Lettish movement partially failed because Germany could not control the Russian commanders.

German policy is still directed towards the maintenance of German influence on Russian forces by (i) grant of equipment, pay, etc., (ii) secret support of the policy of a united Russia. As regards this latter point, it is clear that Germany is willing to go back on her recognition of the independence of Latvia if by so doing she is able to win the support of the Russians. From intercepted orders, etc., Germany appears to realize that the formation of the independent states of Esthonia and Latvia, lying between Germany and Russia and fundamentally hostile to Germany, will severely hamper the relations between the two countries. The attitude of the Germans towards the Ulmanis Government, which personifies national aspirations, has never been more hostile than at present. Herr Winnig, the Minister, remains at Koenigsberg, but his representative Herr Burchardt is at Mitau. Branch missions have been established at Libau and Riga which are in charge of Dr. Kuck and captain von Ludwiger respectively.

As regards the military policy of Germany, the intention of General Count von der Goltz seems to be to remain in Courland until the last possible moment in the hope that some complication may occur which could render the further withdrawal of the German forces unnecessary.

The re-entry of the Russians on the Lettish stage has been neither dignified nor successful. For six month the Letts have seen practically no other Russians in Latvia except the Bolshevik troops with which they were fighting, except a small corps of two hundred under Prince Lieven, who, to his credit be it said, remained at the front even in the darkest days of the Bolshevik successes. By the help of the Germans, Latvia was gradually liberated, but behind the German front there sprung up Russian armies, armed and equipped by the Germans. They came from Warsaw and from Germany, and in a short time their numbers increased from 200 to 5000, and it was announced that further reinforcements were expected. The Letts feared that the Germans, while making a semblance of leaving the country, would in reality hand over the Government to Russian troops in their pay.

On June $24^{\text {th }}$ the Germans informed the Balts of their intention to evacuate Libau, and the latter, having no Balt troops ready, immediately sent a detachment of Lieven's Russian troops to take the place of the retreating German garrison. The Commander of the Russian troops was Colonel Kanep, a Russian officer who had come into Courland from Warsaw, and who was chosen for his post because of his military qualifications. On his staff were several pro-German agents of the pan-Russian group, and it was clearly their intention to keep Libau as a Russian base. The Balts encouraged the scheme because they hoped that the Russians would help them to maintain their ascendancy in Courland. The plot failed because Colonel Kanep, against the orders of Prince Lieven's staff, placed himself at the disposal of the Entente, and shortly afterwards, acting contrary to the 
instructions of the Russian authorities in Mitau, obeyed those of General Yudenich, conveyed to him by General Gough, to move his troops to the Narva front. Libau then come into full possession of the Letts who appointed a Civil Governor to act under a British Military Governor.

The evacuation of Libau by the Russians was a severe blow to the German and Russian intrigues at Mitau, and the embarkation of Colonel's Kanep force and the attention which they received from the Allies, brought over further Russian forces to our side, and shortly afterwards Prince Lieven himself broke away from German entourage and moved from Mitau to Riga.

The presence of General von der Goltz and of the German and Russian troops at Mitau had a very disquieting effect on the population at Riga, but the situation was relieved when General Gough conveyed to Prince Lieven General Judenitch's order that Lieven's troops should also be transported to the Narva front. As in the case of Colonel Kanep's troops, so also in this case every obstacle was placed in the way of their departure. However, on July $22^{\text {nd }} 1500$ Russians embarked at Riga on the SS "Saratov" for Narva, and arrangements were made for the shipment of further Russian detachments.

As the Germans have been separated from the Baltic Landeswehr, which Colonel Alexander is reorganizing at Tukkum, the German forces are being isolated. The Russian soldiers who sailed on the SS "Saratov" belonged to the Tula division who had originally formed part of the Red Army but had mutinied at Homeland after killing the Bolshevik commissars had joined Petliura's army in the Ukraine and had reached Mitau through Warsaw and Germany. Their recent defection to the Entente may well-nigh constitute the death blow to the scheme for German-Russian cooperation in Latvia. So far, the Russian forces operating against the Bolsheviks have been unable to establish any base at a Lettish port.

The fact that the Russians returned here in the train of the hated Germans has greatly lowered their prestige in the eyes of the Letts. The Russians have further damaged their position locally by acting in a tactless manner and by letting the people know that in their opinion nothing has changed and that they considered Latvia still as a mere province of Russia. They made too much display of the Russian flag and of Russian national anthems, and their presence only served to remind the people of the hated Russian regime.

Letts who are best in touch with the situation in Russia do not expect that order will be re-established in that country for many years to come, and they are not looking to Russia for any assistance whatever. Meanwhile the Lettish national movement and the desire for complete independence is getting stronger, especially since the collapse of the Balts. The Letts are no yet conscious of their own shortcomings and of the difficulties of forming a Government, and their one desire is to be freed both the Germans and the Russians. The Letts and the Esthonians desire that their independence should be recognized both by the allies and Russia, and then as independent sovereign States they would negotiate with Russia about economic matters. As regards political matters, they desire to have no connection whatever with Russia, and they do not wish to send delegates to a central Russian Diet in the same way that Bavaria sends its representatives to the German Imperial Landtag. They are most anxious that there should be no Russian interference in the affairs of Latvia.

As regards economic matters, the Letts will, both in their own interest and in that of Russia, grant every facility for transit trade. The Minister President expects that 
Windau - the terminus of a railway from Dvinsk, Moscow, Moscow - Siberia - and Riga, which is also terminus for the railway, will be free ports, and that goods in transit will only have to pay nominal charges. The broad gauge would be used so that Russian trains would run straight into the port. Every facility would be granted to Russian trade, and as regards transit trade, railway, postal, and telegraphic facilities, the Letts would be willing to negotiate conventions with the Russians of a far-reaching nature.

I am sending a copy of this despatch to General Sir H. Gough.

Source: National Archives (United Kingdom), Foreign Office, 371/3615/398-401.

\section{Dokuments Nr. 2}

Lielbritānijas Ārlietu ministrijas pārstāvja Herberta Granta-Vatsona ${ }^{28}$ ziṇojums ārlietu sekretāra (ministra) vietas izpildītājam Džordžam Kērzonam. ${ }^{29}$ Rīga, 1919. gada 23. jūlijs.

Milord, atsaucoties uz manu ziņojumu Nr. 39 šī mēneša 2. datumā, man ir tas gods ziṇot, ka Vācijas politiku pret Baltijas valstīm joprojām vada galvenokārt Herr ${ }^{30}$ Vinnigs, ${ }^{31}$ kurš papildus saviem Austrumprūsijas valsts komisāra pienākumiem darbojas arī kā Vācijas pārstāvis Latvijā un Igaunijā. Viņam ir liels iespaids Austrumprūsijas aprindās un arī lielākajā daḷā sociālistu Berlīnes; taču tie, kas labi pazīst viṇa darbu, stāsta, ka viņš nav tālredzīgs un tam nepiemīt nekāda realitātes izpratne. [Alkoholisko] dzērienu un citu stimulējošo vielu iespaidā viņš ātri aizraujas ar jaunām idejām, taču, cik tas skar Latviju, politika, ko tas atbalstījis, bijusi oportūnistiska. Kad decembrī uzliesmoja revolūcija, ${ }^{32}$ viņš strādāja, lai tiktu atzīta Baltijas valstu neatkarība un stiprināti vietējie nacionālie spēki, izveidojot barjeru pret boḷševiku apdraudējumu. Tomēr šie spēki izrādījās naidīgi pret Vāciju. Vēlāk, kad Polijas armijas izaugsme šķita apdraudam Austrumprūsiju, viņš atbalstīja Staatenbund ${ }^{33}$ izveidi, kur ietilptu Austrumprūsija, Lietuva un Latvija, taču atkal nespēja saskatīt, ka šāds plāns ir lemts neveiksmei milzịgu nacionālo pretrunu dēḷ. Nesenāk realizētā Vācijas politika, formējot krievu spēkus Kurzemē, kas atrastos ciešā saskarē ar Vāciju, lai noturētu boḷševiku fronti un kontrolētu latviešu kustību, daḷēji ir izgāzusies, jo Vācija nespēja kontrolēt krievu komandierus.

Vācijas politika joprojām ir virzīta uz vācu iespaida saglabāšanu pār krievu spēkiem ar (i) ekipējuma, algas u. c. pieškiršanu, (ii) slepenu politiku, kas atbalsta vienotās Krievijas politiku. Par pēdējo punktu ir skaidrs, ka Vācija ir gatava atgriezties pie Latvijas neatkarības atzǐ̌̌anas, ja tādā veidā spēs panākt krievu atbalstu. No pārtvertajām pavēlēm u. c. izskatās, ka Vācija apzinās: neatkarīgu un būtībā Vācijai naidīgu valstu, Igaunijas un Latvijas, izveidošana starp Vāciju un Krieviju ievērojami traucēs abu valstu attiecības. Vāciešu attieksme pret Ulman̦a ${ }^{34}$ valdību, kas iemieso nacionālos centienus, nekad nav bijusi naidīgāka kā pašlaik. Herr Vinnigs, ministrs, ${ }^{35}$ paliek Kēnigsbergā, ${ }^{36}$ bet viṇa pārstāvis Herr Burhards ${ }^{37}$ ir Jelgavā. Pārstāvniecības nodaḷas - misijas - ir izveidotas Liepājā un Rīgā attiecīgi Dr. Kỉka ${ }^{38}$ un kapteiņa fon Ludvigera ${ }^{39}$ vadībā.

Runājot par Vācijas militāro politiku, izskatās, ka ǵenerāla grāfa fon der Golca nodoms ir palikt Kurzemē līdz pēdējam iespējamajam brīdim cerībā, ka var rasties kādi sarežǵījumi, kas novērstu tālāku nepieciešamību izvest vācu spēkus.

Krievu atgriešanās uz Latvijas [politiskās] skatuves nebija ne cienīga, ne veiksmīga. Sešus mēnešus latvieši praktiski neredzēja citus krievus kā vienīgi boḷševiku karaspēku, ar kuru viṇi cīnījās, atskaitot nelielu, divus simtus vīru lielu vienību firsta Līvena vadībā, ${ }^{40}$ 
kura gods godam palika frontē pat tumšākajās boḷševiku panākumu dienās. Ar vāciešu palīdzību Latvija tika pakāpeniski atbrīvota, taču aiz vācu frontes veidojās krievu armijas vienības, ko apbruṇoja un ekipēja vācieši. Tās ieradās no Varšavas un Vācijas, un īsā laikā to skaits pieauga no 200 līdz 5000, tika paziṇots, ka tiek gaidīti tālāki papildinājumi. Latvieši baidījās, ka vācieši, radot šḳietamību par valsts teritorijas atstāšanu, īstenībā var nodot situācijas kontroli vinu algotam krievu karaspēkam.

24. jūnijā vācieši informēja vācbaltiešus par savu nodomu atstāt Liepāju, un pēdējie, kuru rīcībā nebija brīvu vienību, nekavējoties nosūtīja Līvena krievu nodaḷas vienību nomainīt aizejošo vācu garnizonu. Krievu karaspēka [vienības] komandieris bija pulkvedis Kaneps, ${ }^{41}$ krievu virsnieks, kas ieradies Kurzemē no Varšavas un izvēlēts šim amatam militārās pieredzes dēḷ. Viṇa štābā atradās vairāki provāciski aǵenti no pankrievu grupas, ${ }^{42}$ un bija skaidri redzams viṇu nodoms paturēt Liepāju kā krievu bāzi. Vācbaltieši atbalstīja šo nodomu, jo cerēja, ka krievi varētu tiem palīdzēt saglabāt viņu ietekmi Kurzemē. Sazvērestība neizdevās, jo pulkvedis Kaneps, pretēji firsta Līvena štāba pavēlēm, nodeva sevi Antantes rīcībā un drīz pēc tam, darbojoties pretēji instrukcijām, ko deva krievu varas iestādes Jelgavā, pakḷāvās Judeņiča ${ }^{43}$ rīkojumam, ko viṇam nodeva generālis Gofs, - pārvietot karaspēku uz Narvas fronti. Pēc tam Liepāja nonāca pilnīgā latviešu varā, tie iecēla civilo gubernatoru, kas darbojas britu militārā gubernatora pakḷautībā. ${ }^{44}$

Krievu evakuācija no Liepājas bija stiprs trieciens vācu un krievu intrigām Jelgavā, bet pulkveža Kanepa spēku uzkāpšana uz kuğa un uzmanība, ko krievu karavīi saņēma no sabiedrotajiem, veicināja nākamo krievu spēku pāriešanu mūsu pusē, un neilgi pēc tam pats firsts Lìvens sarāva saites ar apkārtējiem vāciešiem un pārvietojās no Jelgavas uz Rīgu.

Ģenerāḷa fon der Golca un vāciešu karaspēka klātbūtne Jelgavā izraisīja lielu nemieru Rīgas iedzīvotājos, taču situācija uzlabojās, kad ǵenerālis Gofs nodeva firstam Lìvenam ǵgenerāla Juden,iča pavēli, saskaņā ar to viņa karaspēks bija jāpārvieto uz Narvas fronti. Tāpat kā pulkveža Kanepa karaspēka gadījumā, arī šoreiz vienības aizbraukšanai tika likti visi iespējamie šķēršlı.i. Tomēr 22. jūlijā 1500 krievu Rīgā uzkāpa uz tvaikoṇa Saratov klāja, lai dotos uz Narvu, vienlaikus tika gatavota pārējo krievu vienību nosūtīšana pa jūras ceḷu. ${ }^{45}$

Tā kā vācieši ir bijuši atdalīti no Baltijas landesvēra, kuru pulkvedis Aleksanders reorganizē Tukumā, vācu spēki tiek izolēti. Krievu karavīri, kuri aizbrauca ar tvaikoni Saratov, bija no Tulas divīzijas, kas sākotnēji atradās Sarkanās armijas sastāvā, bet tad dzimtenē

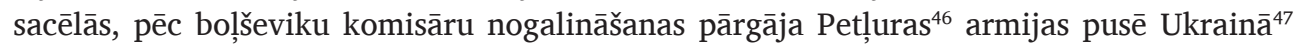
un pēc tam sasniedza Jelgavu, ejot cauri Varšavai un Vācijai. Viṇu nesenā pāriešana Antantes pusē var izrādīties gandrīz nāvējošs trieciens vācu un krievu sadarbības plāniem Latvijā. Līdz šim laikam krievu spēki, kas cīnās pret boḷševikiem, nav spējuši izveidot nekādu bāzi Latvijas ostā.

Fakts, ka krievi šeit atgriezās ienīsto vāciešu vilcienā, lielā mērā pazemināja vinuu prestižu latviešu acīs. Krievi turpināja graut savu prestižu, rīkojoties netaktiski un liekot cilvēkiem saprast, ka, pēc viņu domām, nekas nav mainijies un tie joprojām uzskata Latviju tikai par Krievijas provinci. Viṇi pārlieku daudz demonstrēja Krievijas karogu un dziedāja Krievijas himnu, un viṇu klātbūtne vienīgi atgādināja cilvēkiem par ienīsto krievu režīmu.

Latvieši, kuri labi pārzina situāciju Krievijā, neuzskata, ka šajā valstī tiks atjaunota kārtība daudzu tuvāko gadu laikā, un viṇi nesagaida no Krievijas nekādu palīdzību. Tikmēr latviešu nacionālā kustība un vēlme pēc pilnīgas neatkarības kḷūst stiprāka, sevišḳi 
pēc vācbaltiešu sabrukuma. Latvieši vēl neapzinās paši savus trūkumus un valdības formēšanas grūtības, un vinuu vienīgā vēlēšanās ir atbrīvoties gan no vāciešiem, gan krieviem. Latvieši un igauņi vēlas, lai viṇu neatkarību atzīst gan sabiedrotie, gan krievi, un tad viṇi kā neatkarīgas valstis varētu runāt ar Krieviju par ekonomiskām lietām. Attiecībā uz politiskiem jautājumiem viṇi nevēlas nekādu saikni ar Krieviju, un viṇi negrib sūtīt pārstāvjus uz centrālo Krievijas parlamentu tādā veidā, kā Bavārija sūta tās pārstāvjus uz Vācijas impērijas landtāgu. Visvairāk viņus uztrauc, lai nebūtu nekādas Krievijas iejaukšanās Latvijas lietās.

Par ekonomiskajiem jautājumiem latvieši gan savās, gan Krievijas interesēs piekritīs katrai iespējai uzsākt tranzīta tirdzniecību. Ministru prezidents domā, ka Ventspils, kas ir dzelzcel̦a Daugavpils, Maskava, Maskava-Sibīrija galastacija, un Rīga, kas arī ir galastacija, būs brīvostas un par tranzītprecēm būs jāmaksā tikai nominālas maksas. Lielo dzelzcel̦a sliežu platumu varētu izmantot tā, ka krievu vilcieni iebrauktu tieši ostā. ${ }^{48}$ Tiktu sniegta katra iespēja attīstīt krievu tirdzniecību, ciktāl tas attiecas uz tranzīttirdzniecību, dzelzcel̦u, pasta un telegrāfa iekārtām, un latvieši būtu gatavi apspriest ar krieviem plaša rakstura konvencijas.

Es nosūtu šī ziņojuma kopiju ǵenerālim seram H. Gofam.

Avots: National Archives (United Kingdom), Foreign Office, 371/3615/398-401.

\section{ATSAUCES UN SKAIDROJUMI}

${ }^{1}$ Sk.: EDGARS ANDERSONS. Latvijas vēsture 1914-1920. Stockholm 1967, 465.-471. lpp.

${ }^{2}$ Par situāciju Rīgā aplūkojamajā laikā sk. arī: ĒRIKS JĒKABSONS. Amerikāṇi Rīgā: Amerikas palīdzības administrācija 1919. gada jūnija beigās - jūlija vidū, darbības otrais posms. In: Latvijas Arhīvi 2014, Nr. 1/2, 119.-147. lpp.

${ }^{3}$ Sk.: ĒRIKS JĒKABSONS. Strazdumuižas pamiers 1919. gada 3. jūlijā un tā tiešās sekas: Lielbritānijas misijas vadītāja Stīvena Talentsa redzējums. Truce of Strazdmuiža in July 3, 1919 and its Direct Consequences: Perspective of Stephen Tallents, British Commissioner for the Baltic Provinces. In: Latvijas Universitātes Žurnāls. Vēsture 2017, Nr. 3, 171.-186. lpp.

${ }^{4}$ Sīkāk sk.: KRISTAPS PILDIN̦š. Militāri politiskais stāvoklis Latvijas Atbrīvošanas kara 3. posmā no 1919. gada 3. jūlija līdz 8. oktobrim. Mağistra darbs. Rīga: LU Vēstures un filozofijas fakultāte, 2015 (vadītājs $\overline{\mathrm{E}}$. Jēkabsons), 22.-26. lpp.

${ }^{5}$ Sk.: ĒRIKS JĒKABSONS. Stāvoklis Latvijā pēc Cēsu kaujām: Sabiedroto misijas vadības un vācu pavēlniecības sarunas 1919. gada 19. jūlijā Vintapos pie Olaines stacijas. Situation in Latvia after Cēsis battles: Talks between the leadership of Allies' Mission and the German Headquarters on 19 July 1919 in Vintapi near Olaine railway station. In: Latvijas Arhīvi 2016, Nr. 3/4, 86.-107. lpp.

${ }^{6}$ National Archives (United Kingdom), Foreign Office, 371/3615/488 (Report, Grant-Watson to Curzon, 1919, July 25).

${ }^{7}$ Huberts Delapērs Gofs (Gough, 1870-1963), Lielbritānijas armijas generālleitnants. Pirmā pasaules kara laikā 5. armijas pavēlnieks, 1919. gadā sabiedroto militārās misijas vadītājs Baltijas valstīs.

${ }^{8}$ Acīmredzot ir runa par Francijas militārās misijas pārstāvjiem poḷu karaspēka ieṇemtajā Grodņā, uz to norāda arī nākamajā teikumā pieminētais Lielbritānijas Militārās misijas Polijā vadītāja vietnieks A. Kartons de Viarts, kurš, iespējams, par to informēja H. Gofu.

${ }^{9}$ Lielbritānijas karjeras vicekonsuls Rīgā 1919. gadā bija H. T. Hols (Hall).

${ }^{10}$ Adrians Kartons de Viarts (Carton de Wiart, 1880-1963), beḷ̂́gu-îru izcelsmes Lielbritānijas armijas ǵenerālmajors, vēlāk ǵgenerālleitnants, ar savu varonību leǵendārs vairāku karu dalībnieks. 1918.-1920. gadā darbojās Lielbritānijas militārajā misijā Polijā. 
11 Šajā laikā (1919. gada jūnija beigās - jūlija sākumā) Lielbritānijas Kara flotes kuǵu vecākā jūras virsnieka funkcijas Liepājā pildīja pats 2. vieglo kreiseru eskadras komandieris komodors, vēlākais admirālis Arturs Dafs (Duff).

12 1919. gada jūnijā R. fon der Golcs ignorēja H. Gofa aicinājumu tikties ar viṇu Valkā, lai atrisinātu konfliktu pie Cēsīm.

${ }^{13}$ Rīdigers fon der Golcs (von der Goltz, 1865-1946), Vācijas armijas genenerālmajors. 1919. gadā 6. rezerves korpusa komandieris Latvijā un Lietuvā.

${ }^{14}$ Runa ir par t. s. Cēsu kaujām.

${ }^{15}$ Lìdz Otrajam pasaules karam izplatīts vārds arī latviešu valodā, ar kuru apzīmēja oficiālu apsveikuma tekstu.

${ }^{16}$ H. Gofs no Helsinkiem Liepājā ieradās 22. jūnijā, pēc tam atgriezās Helsinkos, bet Rīgā ieradās 8. jūlijā (devās atpakal uz Tallinu 10. jūlijā). Runa ir par Latviešu tirgotāju savienības viṇam dāvāto adresi, kurā viņš apsveikts kā "mazo tautu brīvības aizstāvju" pārstāvis pateicībā par sabiedroto izrādìto atbalstu Latvijas tautai, un, pateicoties tam, pastāv cerība uz "jaunas dzìves sākumu uz drupām".

${ }^{17}$ Herberts Hūvers (Hoover, 1874-1964), ASV uznēēējs, valstsvīrs, prezidents no 1929. līdz 1933. gadam. Pirmā pasaules kara laikā vadīja palīdzības akciju Beḷgijai, no 1917. gada ASV Pārtikas administrācijas, no 1919. līdz 1923. gadam - Amerikas Palīdzības administrācijas vadītājs, sniedza palīdzību Eiropas valstīm, no 1919. gada aprīla arī Latvijai. 1919. gada jūnijā un jūlijā noteikti aizstāvēja nostāju, ka nepieciešama sadarbība ar vācu okupācijas iestādēm pārtikas izdalē Latvijā, bet tas nepatika Lielbritānijas pārstāvjiem.

${ }^{18}$ Alfrēds Flečers (Fletcher, 1875-1959), Vācijas armijas majors. No 1919. gada 1. februāra līdz jūlijam - Baltijas landesvēra komandieris, 1919. gada jūnijā arī Rīgas pilsētas militārais gubernators. Pēc tam atgriezās Vācijā.

${ }^{19}$ H. Grants-Smits kḷūdijjās, A. Flečers bija majors. Acīmredzot kḷūdu izraisīja A. Flečera augstais amats.

${ }^{20}$ Runa ir par Amerikas Palīdzības administrācijas Rīgas apakšmisijas vadītāja Džordža Felkera (Felker) 26. jūnija ziņojumu misijas vadītājam Džonam Grūmam (Groome) Liepājā. Tikko Rīgā atgriezušās misijas vadītājs šajā dienā bija tiešām ticies ar A. Flečeru un rakstīja par igaunu spēku tuvošanos, kas apdraud sakaru līnijas karaspēkam, kurš cīnās pret boḷševikiem. Flečers norāda, ka igaunu tālākas virzības gadījumā Rīgā kārtību būs grūti nodrošināt, jo kaujasspējīgais karaspēks atrodas frontē, tāpēc prasa, lai sabiedrotie nekavējoties iejauktos un panāktu pamiera noslēgšanu, turklāt lūgumam pievienojās pats Felkers, atzīmējot, ka tas jādara nekavējoties. Savukārt 27. jūnijā pēc tikšanās ar latviešu brigādes komandieri Jāni Balodi Dž. Felkers ziņoja, ka neapstiprinās Flečera teiktais par to, ka bol̦ševiki ien̦ēmuši Krustpili un Balodis pieprasījis papildinājumus savām frontē esošajām vienībām, jo stāvoklis tajā ir mierīgs. Tomēr viňš joprojām pauda bažas par sekām, kādas varētu būt igauṇu karaspēka iebrukumam Rīgā, jo vācu karaspēks atkāpjoties varētu nopietni bojāt pilsētas infrastruktūru, apgādes un sanitāro sistēmu, un atkārtoti uzsvēra nepieciešamību pēc "nekavējošas akcijas", lai novērstu "igauṇu okupāciju". Atbildē Dž. Grūms 28. jūnijā norādīja arī, ka abās telegrammās sniegtā informācija ir zināmā mērā pretrunīga.

${ }^{21}$ Harolds Aleksanders (Alexander, 1891-1969), Lielbritānijas armijas pulkvežleitnants, vēlāk feldmaršals. No 1919. gada pavasara militārās misijas virsnieks Baltijas valstīs, no 1919. gada jūlija līdz 1920. gada aprīlim - Latvijas armijas Vācu zemessargu (reformētais landesvērs) komandieris.

${ }^{22}$ Saskaņā ar Strazdumuižā noslēgto pamieru no landesvēra bija jāizslēdz visi vācbaltiešiem nepiederīgie karavīi, pēc tam to iekḷaujot Latvijas armijā. Tas tika noslēgts 1919. gada augusta beigās, kad vienība kā Latvijas armijas Vācu zemessargi tika pārvietota no Tukuma uz Austrumu fronti.

${ }^{23}$ Alfreds Bērts (Burt, 1876-1949), Lielbritānijas armijas brigādes genenēālis, no 1919. līdz 1920. gadam - militārās misijas vadītājs Latvijā. 
${ }^{24}$ Minētais ir pārspīlējums, A. Bērts Latvijas armijas izveidošanu nevadīja, kā var saprast no ziņojuma, kaut arī Lielbritānijas misija, īpaši vasarā, sniedza tai ievērojamu atbalstu (īpaši Liepājā).

${ }^{25}$ Stīvens Talentss (Tallents, 1884-1958), Lielbritānijas valsts ierēdnis, kara laikā - virsnieks, pulkvežleitnants. No 1919. gada februāra - politiskās misijas vadītājs Baltijas valstīs.

${ }^{26}$ Oriǵinālajā tekstā autors piel̦āvis kḷūdu, jādomā, izlaižot kādu vārdu.

${ }^{27}$ Anatols Līvens (Lieven, 1873-1937), Mežotnes muižas īpašnieks, Krievijas armijas rotmistrs. No 1919. gada sākuma krievu vienības komandieris landesvēra sastāvā, no 2. jūlija - formāli Rietumkrievijas Brīvprātīgo armijas komandieris, taču jau jūlija otrā pusē vienības tika pārvietotas uz Narvu un iekḷautas Ziemel̦rietumu Krievijas Brīvprātīgo armijā.

${ }^{28}$ Herberts Adolfuss Grants-Vatsons (Grant-Watson, 1881-1971), Lielbritānijas Ārlietu ministrijas ierēdnis, diplomāts. 1919. gadā - pārstāvis Baltijas valstīs, vēlāk vēstnieks dažādās valstīs. 1965. gadā publicēta H. Granta-Vatsona grāmata The Latvian Republic: the struggle for freedom.

${ }^{29}$ Džordžs Kērzons (Curzon, 1859-1925), Lielbritānijas valsts ierēdnis, valstsvīrs. 1919. gadā aizvietoja Parīzes Miera konferencē esošo ārlietu sekretāru Balfūru, no 1919. gada oktobra līdz 1924. gadam - ārlietu sekretārs.

${ }^{30}$ Herr (vācu val.) - kungs.

${ }^{31}$ Augusts Vinnigs (Winnig, 1878-1956), Vācijas valsts ierēdnis, sociāldemokrāts. No 1918. gada novembra - Austrumprūsijas un Rietumprūsijas valsts komisārs, generālpilnvarotais pārstāvis Baltijas valstīs, no 1919. līdz 1920. gadam - Austrumprūsijas oberprezidents.

${ }^{32}$ Revolūcija Vācijā sākās 1918. gada novembrī.

${ }^{33}$ Staatenbund (vācu val.) - valstu konfederācija, savienība.

${ }^{34}$ Kārlis Ulmanis (1877-1942), Latvijas valstsvīrs, no 1918. līdz 1921. gadam - Pagaidu valdības Ministru prezidents.

${ }^{35}$ Ziņojuma autors, pats būdams diplomāts, šeit lieto daḷu no diplomātisko pārstāvju rangā ietvertā sūtna nosaukuma - sūtnis un pilnvarotais ministrs. A. Vinnigs tāds oficiāli nevarēja būt.

${ }^{36}$ Kēnigsberga - Austrumprūsijas galvaspilsēta, tagadējā Kaḷininingrada Krievijā.

${ }^{37}$ Vilhelms Burhards (Burchard, no 1925. gada - Burchard-Motz, 1878-1957), Vācijas armijas rezerves rotmistrs (kapteinis), no 1915. gada ierēdnis Kurzemes militārās pārvaldes Centrālajā nodaḷā, no 1918. gada Vācijas generālpilnvarotā Baltijas zemēs vietnieks.

${ }^{38}$ R. Kīks (Kück), juridisko zinātņu doktors. Darbojās Liepājā vismaz no 1919. gada janvāra, 1919. gada vasarā - Vācijas pārstāvis Liepājā, turpināja darbību rudenī. 1920. gada martā aizbrauca uz Vāciju saistībā ar pases termiņa izbeigšanos, par ko draudēja administratīvs sods.

${ }^{39}$ Fon Ludvigers, Vācijas armijas kapteinis, 1919. gada pavasarī dienēja vācu pārstāvniecībā Liepājā, pēc tam Rīgā.

${ }^{40}$ Runa ir par landesvēra Krievu nodaḷu A. Līvena vadībā.

${ }^{41}$ Dāvids Kaneps (Kanep, 1878-1969), Krievijas armijas virsnieks, 1919. gadā A. Līvena nodalas, Ziemeḷrietumu Krievijas Brīvprātīgo armijas pulkvedis, bataljona komandieris. Vēlāk Igaunijas armijas pulkvežleitnants. Pēc izcelsmes igaunis.

${ }^{42}$ Acīmredzot ziṇojuma autors lieto vārdu pan-Russian izplatītā pan-Slavic vietā (panslāvu kustība, kuras mērḳis bija apvienot visas slāvu tautas Krievijas vadībā), ar to saprotot šovinistiski noskaņotu personu grupu.

${ }^{43}$ Nikolajs Judeņičs (Judenich, 1862-1933), Krievijas armijas infantērijas generālis. No 1919. līdz 1920. gadam Ziemel̦rietumu Krievijas Brīvprātīgo armijas virspavēlnieks.

${ }^{44}$ Latvijas valdība 1919. gada jūlijā par Lejaskurzemes apgabala priekšnieku iecēla Andreju Bērziṇu.

${ }^{45}$ A. Lìvena vienības un tai piekomandēto krievu nodaḷu nosūtīšana no Rīgas uz Narvu notika vairākos posmos ar dažu dienu starpību. 
${ }^{46}$ Simons Pețiura (Petlyura, 1879-1926), viens no ukraiṇu nacionālās kustības vadītājiem. No 1919. līdz 1920. gadam Ukrainas Tautas Republikas Direktorijas vadītājs.

${ }^{47}$ Krievu historiogrāfijā pastāv viedoklis, ka 1919. gadā dienvidos no Tulas pretinieka pusē tiešām pārgāja Sarkanās armijas divīzija, taču pretinieks bija krievu baltā Donas armija (divīzija iekḷauta šajā armijā kā 1. Tulas Brīvprātīgā kājnieku divizija, no 7. augusta - brigāde); otra versija divīzijas pāriešanas nemaz nebija, un tā tika saformēta no gūstā kritušiem sarkanarmiešiem. Jādomā, taisnība ir ukraiṇu vēsturniekiem, ka divīzijas dạ̦a Baltkrievijas un Ukrainas pierobežā tiešām pārgāja ukraiṇu pusē, neilgu laiku bija iekḷauta Ukrainas Tautas Republikas armijas brigādē, taču pavēlniecība pati to izformēja, nespējot apgādāt un izmantot, tāpēc karavīri paši centušies nokḷūt krievu baltajās armijās, jādomā, dạ̣a - Juden,iča armijā.

${ }^{48}$ Krievijā dzelzcel̦a sliežu platums bija platāks nekā Eiropas valstīs, Pirmā pasaules kara laikā vācu karaspēks no 1915. gada ien̦emtajā Latvijas teritorijā (Kurzemē un Zemgalē) dzelzceḷa sliežu platumu pārveidoja pēc Eiropas standartiem. 